Features, and the matter of annual grants. A memorandum ${ }^{1}$ has been prepared by the retiring Secretary of the British Section and Executive Office, the Rev. Claude de Mestral, who is returning to Canada, where he was granted leave of absence in 1952 from the United Church of Canada to work for ICCLA. His work is being carried on by Miss Freda M. Dearing.

The memorandum is divided into three parts-Principles, Administrative Matters, and Technical Problems. In the first part Mr. de Mestral stresses the necessity for producers of Christian literature to make certain that their publications secure a firm hold on the growing African market. Such publications cannot be merely direct translations of Western works into African languages, and the process of 'Africanization' needs to be carried out in the field of Christian publications no less than in that of Christian organization. A wider range of publications is needed and more use should be made of the increasing number of indigenous African writers. The second part of the memorandum has been specially prepared for the leaders and officials of churches and missions in Africa, secretaries of missionary societies, and overseas mission boards, and discusses practical problems of finance and methods of increasing sales. The third part deals with the Literature Committees, the Bookshops, and the Presses, and contains much detailed technical advice and information. There is a note on the problem of the choice of languages by Bible societies and Literature Committees when new translations or revisions are to be undertaken. This is especially difficult where languages or dialects formerly in use have been superseded by others such as 'trade' languages. It is therefore essential that the languages to be used in any given territory for Christian literature and for Bibles should be carefully and regularly checked. There should be close collaboration between the agents of the Bible societies and the territorial Department of Education or Publications Bureau, or such organisms as IFAN in French territories.

\title{
The International Library of African Music
}

The International Library of African Music, whose Director is Mr. Hugh Tracey, has distributed $£^{2,500}$ worth of its long-playing records to various Universities and Institutions in Africa and in England. This was made possible through a generous grant from Mr. Harry Oppenheimer. The following Universities in Africa have received records: University College of Rhodesia and Nyasaland, Universities of Pretoria, the Witwatersrand, Potchefstroom, Natal, Rhodes University, and Fort Hare, in addition to the Rhodes-Livingstone Institute, the Rhodes-Livingstone Museum, and the National Museum, Bulawayo. The sets in England have been sent to the Pitt Rivers Museum, Oxford; Manchester University; Cecil Sharp House, London; the School of Oriental and African Studies, University of London; and the British Institute of Recorded Sound.

The Library has recently started to produce a series of 'popular' I 2-inch records, which will consist of items which have received Osborn awards during the year and other special issues which are likely to interest a wider public. The first two items in this series have already been issued and contain the prize-winning recordings of 1957 .

The address of the Library is: P.O. Box 138 , Roodeport, Transvaal, Union of South Africa.

\section{Eighth Annual Conference of the Historical Society of Ghana}

THE Eighth Annual Conference of the Historical Society of Ghana was held at Adisadel College, Cape Coast, on I6-1 8 January 1959. Mr. W. F. Conton, Headmaster of the Accra High School, was elected President of the Society for the coming yeat.

I Christian Literature in Africa, by Claude de Mestral. Distributed by the Christian Literature Council, 2 Eaton Gate, London, S.W.r. 
There are now 133 members of the Society, which was founded in 1952 " to promote the study of the history of Ghana and of adjacent territories in West Africa and their peoples'. Its headquarters is in the History Department of the University College of Ghana and there are active branches at Kumasi and Cape Coast.

At the Conference five papers were read: 'Richard Brew : an 18th Century trader at Anomabu', by Margaret Priestley; 'The Migration of cocoa farmers from the early 1890 's to the present day', by Polly Hill; 'Jacobus Elisa Johannes Capitein (1717-47)', by F. L. Bartels; "The role of Anglo-African journals and journalists in the 19th and 2oth Century history of Ghana', by K. A. B. Jones-Quartey; and 'Some developments in Akan administrative practice, I 7 th and 18 th Centuries', by Ivor Wilks.

The Society's Ninth Annual Conference will be held at the Kumasi College of Technology in January, rg6o.

\section{[Communicated by G. W. Irwin]}

\section{Seminar for Anthropological Field Workers in British Central Africa}

ANTHRopologists at present engaged in field work in the Federation of the Rhodesias and Nyasaland met at the University College of Rhodesia and Nyasaland under the auspices of the Department for African Studies for a seminar which lasted from 2 to in June. The following papers were read-Dr. I. Lewis on 'A Classification of African Political Systems', Mr. G. K. Garbett on 'Structural Changes in some Zezuru Villages : I948-I958', Mr. R. Wishlade on 'Modern Sectarian Movements in Nyasaland', Mr. J. Argyle on 'Clan and Lineage amongst the Soli', Dr. R. Apthorpe on 'Nsenga Clan Joking Relationships', Mr. R. Rotberg on 'Growth of Missionary Activities in Northern Rhodesia', Dr. P. Roumeguère on 'Dialectics of Order and Disorder among the Karanga Complex', and Mrs. J. Roumeguère on 'Dynamic Approach to the Kulangu Karanga Complex'.

\section{Seminar on the Place of Vernaculars in Literary Study in African Schools}

A SEMINAR on the place of vernaculars in literary studies in African schools was held at the University College of Rhodesia and Nyasaland over the weekend of 5-7 June. Thirty delegates from Departments of Education, Information Departments, Publications Bureaux, and the University College, together with several individuals who were personally interested in this problem, met to discuss the place that Vernacular Studies should occupy at both primary and secondary levels of education. After an opening address by Professor N. H. MacKenzie the following papers were read-Dr. J. K. Louw on 'The Study of African Vernaculars at Primary School Level', Mr. E. Smith on 'The Use of Vernaculars as the Medium of Instruction in African Primary Schools', Mr. G. Mhlanga on 'Method used in teaching Vernacular in Secondary Schools', Miss M. Gordon on 'What Vernacular Teaching could learn from Methods of Teaching English', Mr. G. Wilson on 'What African Vernaculars can offer for Serious Study', Mr. G. Michongwe on 'The Outlook for Vernacular Literature ', Dr. C. Wake on 'Language Teaching Policy in French Territories ', Mr. P. Stevenson on 'The Teaching of Classics in African Schools'.

\section{East African Institute of Social Research Conference, January I959}

THE following papers were presented and discussed at the East African Institute of Social Research's Conference in January: 'The Arms Trade in Africa in the late Nineteenth Century', by R. W. Beachey; 'The Attack on the Supreme Court in the U.S.A.', by Marjorie Dilley; 'Some Social and Economic Implications of Paternalism in Uganda', by C. Ehrlich; 'Administrative Aspects of the I958 Uganda Elections', by C. F. Engholm; 'The Sudanese 